\title{
THE EFFECT OF INFRASTRUCTURAL INTEGRATION OF REGIONAL TRANSPORT ON TOURISM PROMOTION: THE CASE OF GUILAN PROVINCE, IRAN
}

\author{
Mohammad MALEKI ${ }^{1}$, Saber MOHAMMADPOUR ${ }^{1}$, Seyed Reza AZADEH ${ }^{2}$ \\ ${ }^{1}$ University of Guilan, Rasht, Iran, ${ }^{2}$ University of Isfahan, Isfahan, Iran
}

\begin{abstract}
This article examines the impacts of infrastructural integration of regional transport (IIRT) on tourism and the idea of using IIRT to promote tourism. The process of striving for IIRT requires a number of factors to be operationalized, among which the most common are: multimodal terminals (MMT), shared stops (SST), highway construction and improvement $(\mathrm{HCl})$, and railway construction and improvement $(\mathrm{RCl})$. The aim of this article is to evaluate the impacts of IIRT factors on the factors which lead towards the promotion of tourism. The results showed that Guilan province, despite of profiting with all four major transportation modes, has a lack of infrastructural integration among all transportation modes. Furthermore, it was concluded that IIRT can have a significant effect on the promotion of tourism and it can be used as an approach to promote the tourism industry of Guilan province with using several strategies in this regard.
\end{abstract}

Key Words: infrastructural integration, regional transport, tourism promotion, Guilan province.

\section{Introduction}

Tourism is considered as one of the most important industries and its promotion plays a central role in development (Najdawi 2009, Wang and Chen 2015, Zhang et al. 2015). According to some estimates, tourism accounts for between six and seven percent of the global gross domestic product and for 1 in 11 jobs, making it the world's largest industry. According to UNWTO (2019), international tourist arrivals increased by $5 \%$ worldwide in 2019 , reaching a record of 1.4 billion arrivals, while international tourism receipts increased by $4 \%$, achieving a record of US\$ 1.7 trillion in revenue. Among all activities that lead to tourism promotion, transportation can be considered as a facilitator of the tourism activity and tourism expansion (Israeli and Mansfeld 2003).

Understanding the tourist flow and the factors influencing the relationships that tourists have with the destinations has profound implications for infrastructure and transport development (Zeng and He 2019). Transportation is a key element supporting tourism and one of the most effective factors in the success of the tourism industry. The inextricable relationship between them makes the expansion of tourism as one of the main reasons for the expansion and improvement of transportation (Lumsdon 2000, Sorupia 2005, Yao et al. 2011, Lohmann and Pearce 2012, Mammadov 2012, Turnbull and Griffin 2012, Krejić and Plečić 2016, Van Truong and Shimizu 2017).

It seems that one of the best regional transportation systems to promote tourism is the integrated regional transport system. There is no fully accepted definition of the meaning of integrated transport, however, numerous descriptions and explanations have been provided to better understand the concept of integrated transport, including a series of steps, and many aspects and activities (Potter and Skinner 2000, Nosal and Solecka 2014, Lu et al. 2018). Several definitions and criteria of integrated transportation can be found in different literature (Underdal 1980, May and Roberts 1995, Hine 2000, Potter and Skinner 2000, Janic 2001, 
Ibrahim 2003, Stead 2003, Hull 2005, May et al. 2006, Givoni and Banister 2010, Preston 2010, Nosal and Solecka 2014, Solecka and Żak 2014).

Janic (2001) has attempted to present some of the recent developments and issues related to integrated transport system policies in the European Union (EU). The study defines and uses the term of integrated transport systems for systems providing door-to door passenger transport services and it is believed that integration can occur at different levels and it may involve many aspects and activities (Janic 2001).

In another case, transport integration is defined as a helpful method for people to move around more easily, with less costs and inconveniences of travel (Ibrahim 2003). According to the author (Ibrahim 2003), integration is about traveling via rider-friendly intermodal facilities and interconnections. The author studied the current status of Singapore's public transit system and then, by examining the various aspects of the integrated transport, he presented several solutions towards the improvement of the public transportation of the city (Ibrahim 2003).

Stead (2003) examined the extent to which transport and land-use planning policies are integrated by the local authorities in England.

Transport integration may occur at different levels and it contains different types and forms. There are a number of different types of transport integration presented by different authors (Table 1).

Infrastructural integration is one of the most commonly introduced principles. The concept of infrastructural integration consists of a combination of elements that make up the integrity of a transport network (Nosal and Solecka 2014). The most important of these elements include multi-modal terminals and shared stops for different means of public transportation at regional level, highway construction and the improvement of existing road and rail routes ${ }^{1)}$ (May and Roberts 1995, Potter and Skinner 2000, Hull 2005, Nosal and Solecka 2014, Solecka and Żak 2014). The aim of this article is to evaluate and to discuss the impacts of the infrastructure integration factors on the factors which lead towards the promotion of tourism. In order to show the practical application of the proposed approach, the example of Guilan was used.

\section{Methodology}

The data used in this study are characterized into two sections approaching transportation and tourism individually. The first part on transportation contains the information on the air transport of Guilan, including the location of the airport and the accessibility of other transportation modes to the airport. The second part refers to water transport, which includes information on the harbors of the province and their status of accessibility to each other and the different transportation modes. The last part on transportation, includes the condition of land transport, which is divided into two parts, namely road transport and rail transport. This part opens up with information on land and rail transport networks and it continues with the description of roads and railroads conditions, as well as the location of stations and terminals. The second section dedicated to tourism issues describes the location of tourism attractions and the accessibility of them according to transportation routes and stations.

\section{Transportation}

Research findings are based on data from the Spatial Development Plan (SDP) of Guilan province, published by the Management and Planning Organization of Guilan. The study data

1) The introduced measures are sometimes presented in the modal and spatial integration subcategories. 
The Effect of Infrastructural Integration of Regional Transport on Tourism Promotion: the Case of Guilan Province, Iran

Table 1

Transport integration types

\begin{tabular}{|c|c|c|}
\hline Author(s) & Title & Different types of transport integration \\
\hline $\begin{array}{l}\text { Ibrahim } \\
\text { (2003) }\end{array}$ & $\begin{array}{l}\text { Improvements and } \\
\text { integration of a } \\
\text { public transport } \\
\text { system: the case of } \\
\text { Singapore }\end{array}$ & $\begin{array}{l}\text { Fare integration/Information integration/Physical integration/ } \\
\text { Network integration/Integrated planning }\end{array}$ \\
\hline $\begin{array}{l}\text { May et al. } \\
(2006)\end{array}$ & $\begin{array}{l}\text { The principles of } \\
\text { integration in urban } \\
\text { transport strategies }\end{array}$ & $\begin{array}{l}\text { Integration between policy instruments involving different } \\
\text { modes/Integration between policy instruments involving } \\
\text { infrastructure provision, management, information and pricing/ } \\
\text { Integration between transport measures and land use planning } \\
\text { measures/Integration with other policy areas such as health and } \\
\text { education }\end{array}$ \\
\hline Hine (2000) & $\begin{array}{l}\text { Integration, } \\
\text { integration, } \\
\text { integration... } \\
\text { Planning for } \\
\text { sustainable and } \\
\text { integrated transport } \\
\text { systems in the new } \\
\text { millennium }\end{array}$ & $\begin{array}{l}\text { Integration within and between different types of transport/ } \\
\text { Integration with the environment/Integration with land use } \\
\text { planning/Integration with other policies for education, health and } \\
\text { wealth creation }\end{array}$ \\
\hline Hull (2005) & $\begin{array}{l}\text { Integrated transport } \\
\text { planning in the UK: } \\
\text { From concept to } \\
\text { reality }\end{array}$ & $\begin{array}{l}\text { Integration between authorities/Integration between measures } \\
\text { involving different modes/Integration between measures } \\
\text { involving infrastructure provision, management and pricing/ } \\
\text { Integration between transport measures and land use planning } \\
\text { policies/Integration between transport measures and policies for } \\
\text { the environment/Integration between transport measures and } \\
\text { policies for education, health and wealth creation }\end{array}$ \\
\hline $\begin{array}{l}\text { Potter and } \\
\text { Skinner } \\
(2000)\end{array}$ & $\begin{array}{l}\text { On transport } \\
\text { integration: } \\
\text { a contribution to } \\
\text { better understand- } \\
\text { ing }\end{array}$ & $\begin{array}{l}\text { Functional or modal integration/Transport and planning } \\
\text { integration/Social integration/Environmental, economic and } \\
\text { transport policy integration }\end{array}$ \\
\hline $\begin{array}{l}\text { Preston } \\
(2010)\end{array}$ & $\begin{array}{l}\text { What's so funny } \\
\text { about peace, love } \\
\text { and transport } \\
\text { integration? }\end{array}$ & $\begin{array}{l}\text { Integration of fares, service patterns, terminals/stops and } \\
\text { information within the public transport/Integration of } \\
\text { infrastructure provision, management and pricing for public and } \\
\text { private transport/Integration of passenger and freight transport/ } \\
\text { Integration of (transport) authorities/Integration between } \\
\text { transport measures and land use planning polices/Integration } \\
\text { between general transport policies and the transport policies of } \\
\text { the education, healthcare and social services sectors/Integration } \\
\text { between transport policies and the policies for the environment } \\
\text { and for economic development }\end{array}$ \\
\hline $\begin{array}{l}\text { Solecka and } \\
\text { Żak (2014) }\end{array}$ & $\begin{array}{l}\text { Integration of the } \\
\text { urban public } \\
\text { transportation } \\
\text { system with the } \\
\text { application of traffic } \\
\text { simulation }\end{array}$ & $\begin{array}{l}\text { Integration of different modes of public transportation/Integration } \\
\text { of public and individual transportation/Integration of the } \\
\text { transportation policy with other policies concerning spatial } \\
\text { planning and city management/Spatial integration based on the } \\
\text { application of efficient land use strategies/Infrastructural } \\
\text { integration based on the development of different technical } \\
\text { solutions in the transportation infrastructure/Organizational } \\
\text { integration/Economic integration focused on the introduction of } \\
\text { different measures supporting the sustainability and efficiency of } \\
\text { the public transportation systems }\end{array}$ \\
\hline
\end{tabular}

of transportation, including its qualitative status and the length of different transport routes, were obtained from the second chapter of the SDP, entitled 'Transportation'. Also, the layers of transportation in the ArcGIS software, including the transportation routes, the location of 
transport stations, the harbors and the airport, are provided by the database of the SDP of Guilan.

In order to determine the accessibility of the different zones of the province to transportation modes, the Euclidean distance tool with Fuzzy logic in the ArcGIS software was used for each transport infrastructure individually. Ultimately, in order to obtain the final vision on the transport accessibility of the province, an AHP-based survey using interviews with 20 experts was used for weighting the importance ratio of each infrastructure of transportation.

\section{Tourism}

The tourism based findings are mostly based on the data provided by the Management and Planning Organization of Guilan in the third chapter of the SDP, entitled 'Tourism', in which data such as the number and type of tourist attractions are collected individually by the municipality of each city and they are integrated into maps and tables in the SDP. Also, the location map of tourist attractions is provided by the organization of Handicrafts and Cultural Heritage and the SDP as well.

\section{Results and Discussion}

Guilan province, situated in the North of Iran and the South of the Caspian Sea, has been of interest in this study due to its specific potential of visiting, with a total number of 1043 tourist attractions (cultural, human-made and natural). The regional transport in Guilan is facilitated by four modes of water, air, rail and road transport, which grants different options for travelers in choosing a transportation mode to enter the province. This study steps forward to figure out the presence or the absence of infrastructural integration of transportation in Guilan, and the effect of infrastructural integration on the tourism promotion, which have not been discussed before, then to use a number of strategies based on infrastructure integration in order to promote the tourism industry of Guilan.

\section{Air transport}

Guilan province contains only one airport named Sardar-e jangal international airport, which mostly contains domestic travels, while the only international travels of this airport are limited to Islamic religious countries such as Saudi Arabia, Iraq and Syria. The airport is located in Rasht and in the vicinity of Rasht-Anzali highway which provides a proper road access to the air transport, but it is found that there is the issue of the accessibility of the airport to the terminals of other transportation modes.

The nearest bus stations to the airport are Rasht and Kouchesfahan bus terminals which are respectively in the distance of $11.2 \mathrm{~km}$ and of $19.2 \mathrm{~km}$ from it. This is while there is no bus terminal or bus station in the airport area. Also, the nearest train station from the airport is Pirbazar station, which is located at the distance of $11.4 \mathrm{~km}$ and it is connected to the airport through primary roads. This means that the tourists or travelers who enter the province through air transport have two options to reach the tourist attractions of the province through public transportation: 1. to use a taxi to reach the nearest bus terminal, which is located $19.2 \mathrm{~km}$ from the airport, and then to use the bus to reach the rest of the province; or 2. to take a taxi to reach the nearest train station, which is located $11.2 \mathrm{~km}$ from the airport, and then to reach the rest of the province by using the rail transport. Also, there is the opposite of this case for those who want to reach the airport from the other parts of the province. It is clear that these conditions bring numerous issues for the tourists and all passengers in terms of time, costs, convenience etc.

Water transport

There are two seaports in the province, namely Anzali and Astara, which are located on the 
northern coast of the province. Today, the ports serve as the main terminals for the importation of oil etc. Although water travels are currently limited to freight transport, there is also the potential for passenger transportations.

It was found that Anzali and Astara both have proper access to the highway network of the province. Two major highways of the province, namely Rasht-Anzali and Rasht-Astara, connect these ports to the center of the province and the Sardar-e Jangal airport. Also, the Rasht-Anzali and Rasht-Astara railways that reach both Astara and Anzali ports are under construction, but currently, the nearest train stations to Anzali and Astara are, respectively, in the distance of 36.7 and 180 kilometers from them.

\section{Land transport}

According to the Management and Planning organization of Guilan, the province has a network of roads of varied quality and capacity, totaling about $8347 \mathrm{~km}$. The majority of the land routes of the province are rural roads which cover $77.62 \%$ of the total, while the freeways have the smallest share of the total land routes. The Qazvin-Rasht-Astara railway, of which the most part is located in Guilan, has a length of $205 \mathrm{~km}$.

Studies on the transportation network of Guilan follow that the development of transportation is concentrated in the central parts of the province and the peripheral parts of the Caspian Sea. The rail network is initially connected to the center (Rasht) from the south and then in the future, in the form of a parallel to the Caspian Sea border, it continues to the north to Bandar-e Anzali, to the west to Astara and to the east to Chaboksar and Mazandaran province. The highway network also has an almost similar pattern to the rail network in the province and the only existing freeways with lengths of 10 and $20 \mathrm{~km}$ are located in the south of the province. The southwest and southeast parts of the province, which include a number of important tourism counties, such as Fuman, Masal, Siahkal, and Rasht, lack a proper access to the transportation network. It is while the statistical surveys show that Fuman and Rudsar have the highest total number of tourist attractions in the province, and despite the fact that the highway network is entering the northern parts of these counties, all of their major tourist attractions have no direct access to the highways. For example, the Rasht-Fuman highway enters Fuman from the eastern part of the city, but the major tourist attractions of the city are located in the western parts. Also, in Rudsar, where the highway network enters the city from the northern parts, there are important tourist attractions in the south of the city which have no access to the highway network.

Also, according to the studies, there are currently 27 bus terminals in Guilan and also 7 train stations, namely Manjil Station, Lowshan Station, Rostamabad Station, Emamzadeh Hashem Station, Rasht Station and Pirbazar Station, while only Manjil, Lowshan and Rasht have both a bus terminal and a train station (Fig. 1). On the other hand, Rudbar, despite being on the railroad track, has no train station.

\section{Tourism}

Guilan province is profited by all three types of tourism attractions (natural, human made and cultural-historical). The results indicate that Fuman, with 267 tourism attractions $(25.6 \%$ of the total), ranked the first among all counties, while Rudsar and Amlash ranked the second and third after Fuman, based on the total number of tourist attractions. The information was 


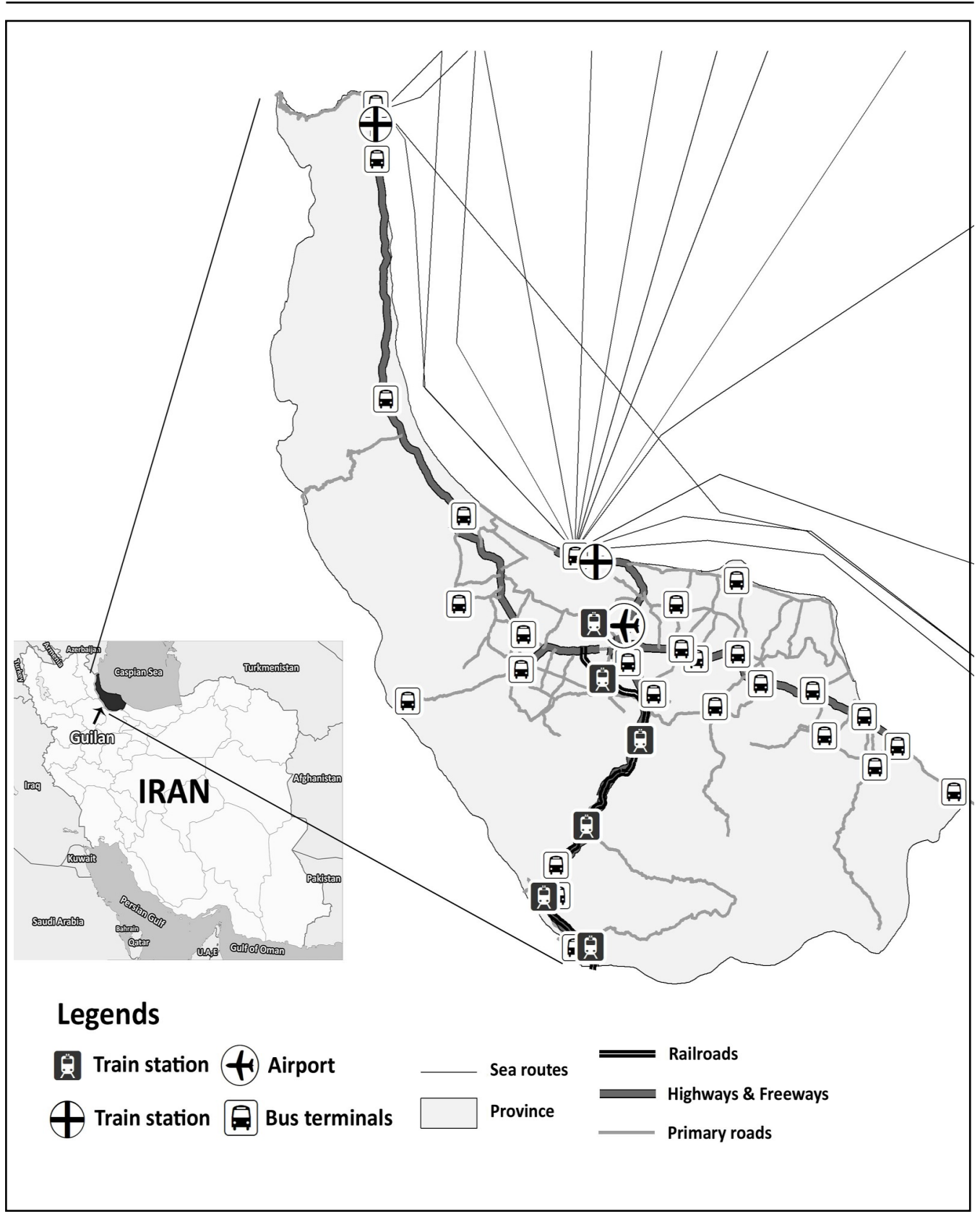

Fig. 1 - Transport network and stations of Guilan province Source: Spatial development plan of Guilan province (2018) 
The Effect of Infrastructural Integration of Regional Transport on Tourism Promotion: the Case of Guilan Province, Iran

obtained from the Organization of Management and Planning of Guilan and the results are shown in the following table (Table 2).

Guilan tourist attractions by city

Table 2

\begin{tabular}{|c|c|c|c|c|c|c|c|c|c|}
\hline Attractions & \multicolumn{2}{|c|}{ Natural } & \multicolumn{2}{|c|}{$\begin{array}{c}\text { Human } \\
\text { made }\end{array}$} & \multicolumn{2}{|c|}{$\begin{array}{l}\text { Cultural- } \\
\text { historical }\end{array}$} & \multicolumn{2}{|c|}{ Total } & \multirow[t]{2}{*}{$\begin{array}{c}\text { Ranking } \\
\text { (based on } \\
\text { total attrac- } \\
\text { tions) } \\
\end{array}$} \\
\hline & $\begin{array}{c}\text { Num- } \\
\text { ber }\end{array}$ & $\begin{array}{c}\text { Per- } \\
\text { centage }\end{array}$ & $\begin{array}{c}\text { Num- } \\
\text { ber }\end{array}$ & $\begin{array}{c}\text { Per- } \\
\text { centage }\end{array}$ & $\begin{array}{c}\text { Num- } \\
\text { ber }\end{array}$ & $\begin{array}{c}\text { Per- } \\
\text { centage }\end{array}$ & $\begin{array}{c}\text { Num- } \\
\text { ber }\end{array}$ & $\begin{array}{c}\text { Per- } \\
\text { centage }\end{array}$ & \\
\hline Astara & 10 & 6.90 & 3 & 5.36 & 4 & 0.48 & 17 & 13.63 & \multirow{17}{*}{$\begin{array}{l}\text { 1) Fuman } \\
\text { 2) Rudsar } \\
\text { 3) Amlash } \\
\text { 4) Rudbar } \\
\text { 5) Rasht } \\
\text { 6) Rez- } \\
\text { vanshahr } \\
\text { 7) Tavalesh } \\
\text { 8) Lahijan } \\
\text { 9) Bandar-e } \\
\text { Anzali } \\
\text { 10) Masal } \\
\text { 11) Siahkal } \\
\text { 12) Lan- } \\
\text { garud } \\
\text { 13) Sowme' } \\
\text { eh Sara } \\
\text { 14) Astara } \\
\text { 15) Astaneh } \\
\text {-ye Ashrafi- } \\
\text { yeh } \\
\text { 16) Shaft }\end{array}$} \\
\hline $\begin{array}{l}\text { Astaneh-ye } \\
\text { Ashrafiyeh }\end{array}$ & 5 & 3.45 & 2 & 3.57 & 3 & 0.36 & 10 & 0.96 & \\
\hline Amlash & 7 & 4.83 & 1 & 1.79 & 143 & 16.98 & 151 & 14.48 & \\
\hline $\begin{array}{l}\text { Bandar-e } \\
\text { Anzali }\end{array}$ & 8 & 5.52 & 9 & 16.07 & 11 & 1.31 & 28 & 2.68 & \\
\hline Rasht & 8 & 5.52 & 17 & 30.36 & 41 & 4.87 & 66 & 6.33 & \\
\hline Rezvanshahr & 3 & 2.07 & 3 & 5.36 & 52 & 6.18 & 58 & 5.56 & \\
\hline Rudbar & 11 & 7.59 & 4 & 7.14 & 79 & 9.38 & 94 & 9.01 & \\
\hline Rudsar & 20 & 13.79 & 4 & 7.14 & 135 & 16.03 & 159 & 15.24 & \\
\hline Siahkal & 11 & 7.59 & 0 & 0 & 14 & 1.66 & 25 & 2.40 & \\
\hline Shaft & 3 & 2.07 & 1 & 1.79 & - & 0.36 & 7 & 0.67 & \\
\hline $\begin{array}{l}\text { Sowme'eh } \\
\text { Sara }\end{array}$ & 5 & 3.45 & 2 & 3.57 & 14 & 1.66 & 21 & 2.01 & \\
\hline Tavalesh & 8 & 5.52 & 0 & 0 & 48 & 5.70 & 56 & 5.37 & \\
\hline Fuman & 13 & 8.97 & 5 & 8.93 & 249 & 29.57 & 267 & 25.60 & \\
\hline Lahijan & 4 & 2.76 & 1 & 1.79 & 27 & 3.21 & 32 & 3.07 & \\
\hline Langarud & 8 & 5.52 & 4 & 7.14 & 12 & 1.43 & 24 & 2.30 & \\
\hline Masal & 21 & 14.48 & 0 & 0 & 7 & 0.83 & 28 & 2.68 & \\
\hline Province & 145 & 100 & 56 & 100 & 842 & 100 & $\begin{array}{c}104 \\
3\end{array}$ & 100 & \\
\hline
\end{tabular}

Source: Spatial development plan of Guilan province (2018)

\section{Transportation routes and accesses}

As mentioned in the previous sections, some parts of the province have no proper access to the transportation system and this section shows the quality of the accessibility of the different zones of the province to all transportation modes. In order to collect data, the Euclidean distance tool in the ArcGIS software and the Fuzzy Logic have been used. According to this 
method, the accessibility of provincial zones to the transportation networks is divided into 4 categories. From 0 to $0-0.2$ as 'Zones with high accessibility', 0.2-0.4 as 'Accessible zones', 0.4 -0.6 as 'Zones with poor accessibility', and 0.6 and above as 'Zones with very poor accessibility'.

There are 10 elements considered to determine the accessibility of the province to road transportation, namely freeways, highways, primary roads gr. 1 , primary roads gr. 2 , primary roads gr. 3 , non-primary roads gr. 1 , non-primary roads gr. 2 , non-primary roads gr. 3 , innercity ways and bus terminals, and all of the mentioned elements are overlapped by different importance ratios using the AHP method.

In order to indicate the accessibility of air and water transport, the distances from the airport

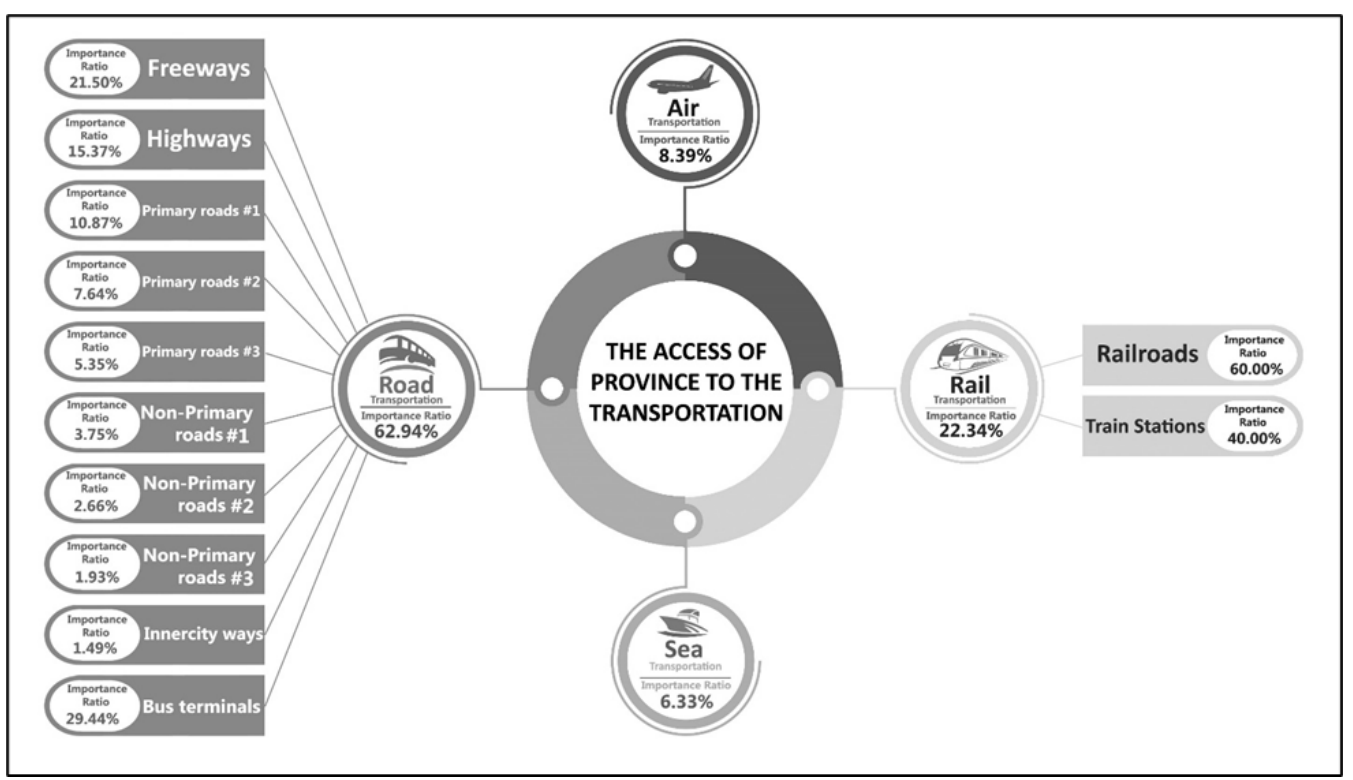

Fig. 2 - The importance ratio of the amount of accessibility of the Province's zones to all transportation modes

and ports are considered, as well as the distances from railways and train stations for the accessibility of rail transport.

Finally, in order to achieve the accessibility of the province to transportation, all transportation modes have been overlapped with different importance ratios determined by using the AHP method. Fig. 2 illustrates the importance ratios of different transportation modes in the Guilan province.

The results indicate that almost $70 \%$ of the zones of the province have proper access to transportation (Fig. 3). The other 30\%, which represent the northwest and southeast parts of the province and include Tavalesh, Rudsar, Rezvanshahr, Siahkal, Amlash, Masal and Rudbar, have the highest percentage of inefficiencies in the accessibility to transportation due to the size of each county.

In summary, it was found that there is no multimodal terminal or shared stop in the province. 


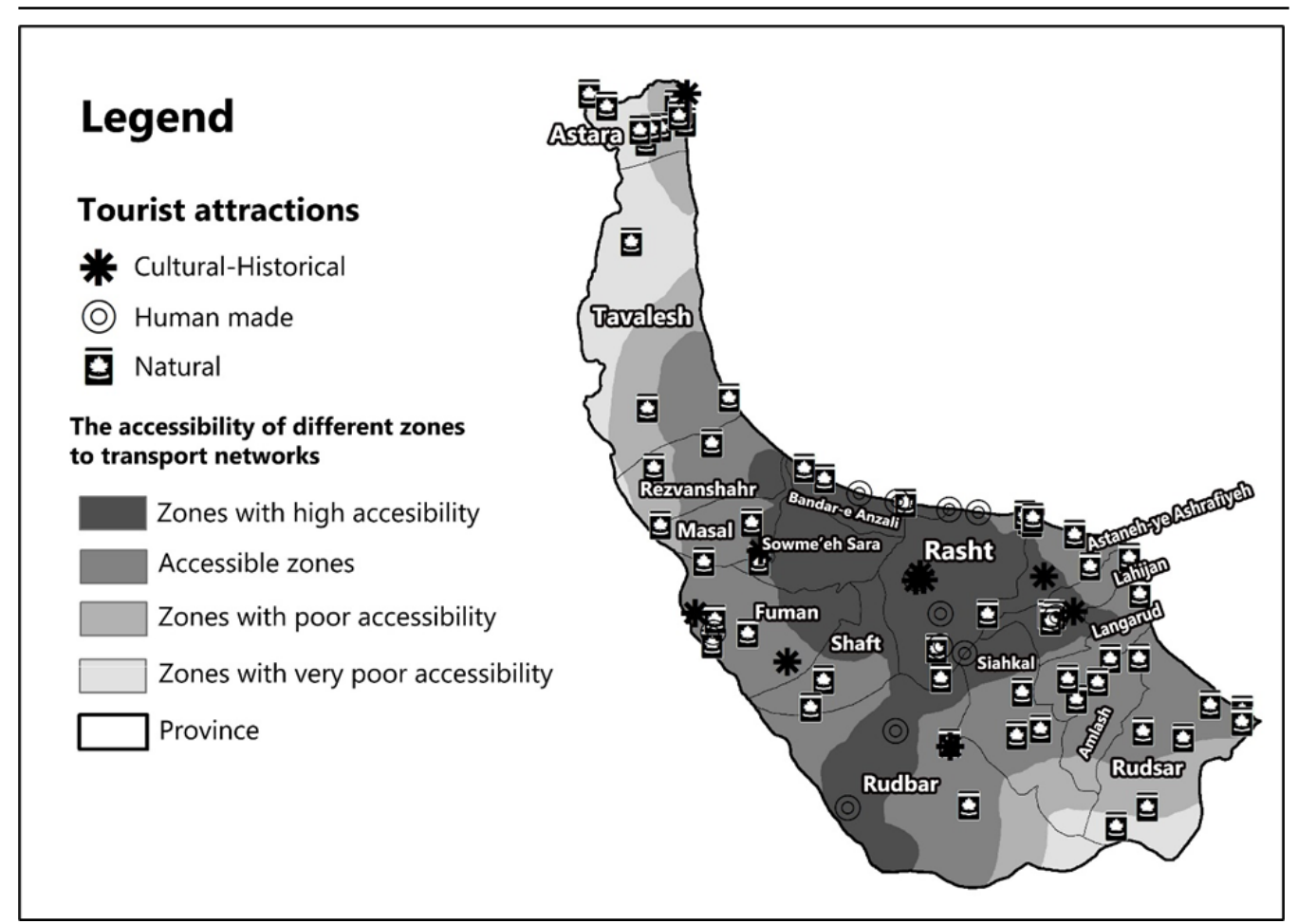

Fig. 3 - Spatial analysis of the accessibility of provincial zones and tourist attractions to all transportation infrastructure

Source: analyzed by the authors based on the data of the Spatial development plan of Guilan province (2018)

Sardar-e Jangal airport, Astara and Anzali ports have no direct access to the rail network and there are many tourist areas that have no proper access to the highway network. This indicates a clear need to construct new highways and to improve the existing ones, as well as constructing railways, multimodal terminals and shared stops with the purpose of connecting different modes of transport and of providing accessibility to tourism attractions.

Therefore, the research has step by step found that there is a lack of integration for the transport infrastructure of Guilan province whilst transportation in the province is facilitated with four modes of regional transport and there is the complete possibility of infrastructure integration of transportation in this province.

According to different literatures, there are a number of effective factors in tourism promotion, including accessibility, mobility, transport and network connectivity, affordability and cost, time, comfort and safety (Crouch and Ritchie 1999, Shin 2005, Tóth and Dávid 2010, Kővári and Zimányi 2011, Mammadov 2012, Santos et al. 2014, La Rocca 2015, Madhuwanthi et al. 2015, Chan and Yuan 2017, Yang et al. 2019). Also, as mentioned in the previous sections, there are various factors in terms of infrastructural integration, namely, multimodal terminals (MMT), shared stops (SST), highway construction and improvement $(\mathrm{HCl})$ and railway construction and improvement (RCI) (May and Roberts 1995, Potter and Skinner 2000, Hull 2005, Nosal and Solecka 2014, Solecka and Żak 2014, Van Truong and Shimizu 2017). The aim of this 
section is to recognize the effectiveness of infrastructural integration factors on the factors affecting tourism promotion.

MMTs and SSTs have analogous functions, practically, and there is the task of connecting several transportation modes to each other, except that MMTs operate at a larger scale than SSTs, but in terms of cost, it is more affordable to construct SSTs. These two factors have direct impacts on tourism promotion.

One of the most considerable transport-based principles in tourism is the accessibility of travelers to different modes of transport, so that travelers have the possibility to access their desired modes of transport, and this possibility can be acquired through MMTs or SSTs. Suppose that a tourist enters Guilan province through air, rail or water transport and he needs to access the public road transport to get to his desired destination, and, due to air, rail and water transport restrictions, the access to that particular location is only possible through road transport. It is effortless for the tourist to have instant accessibility to road transport once they reach the province, and one of the best solutions is to integrate the stations of different modes of transport by the means of MMTs and SSTs. On the other hand, these terminals and stops can create connectivity between different transport networks, which requires the crossing of different transport paths on each other, in order to construct an MMT or SST in a particular location with direct accessibility to several transportation networks. Furthermore, efficient transport connectivity can significantly reduce travel time and costs for the tourists (Peng et al. 2015). If travelers have no direct access to different transport modes, they are compelled to use a taxi to reach their desired transport stop. This not only increases costs and it reduces the affordability of tourists to use transportation, but it also causes them to waste a lot of time in switching the transport modes. On the other hand, the accessibility of the stations has a direct influence on the comfort. MMTs and SSTs provide an instant access to different transport modes stations and it is much safer and more convenient for the travelers to change the transport modes without using a taxi or other private vehicles (Gutiérrez et al. 2019).

$\mathrm{HCl}$ and $\mathrm{RCl}$ are the first steps of infrastructural integration. Regardless of the importance of MMTs and SSTs, transport integration cannot be implemented if there is a lack of efficient roads and railways. Highways and railways make a crucial contribution to tourism promotion. Functional highways and railways facilitate the proper access of tourists to tourist attractions, as well as the different transport stations. In a region with numerous tourist attractions like Guilan, while each one is located in different parts of the province, it requires efficient transport networks to provide accessibility to all attractions through different modes of transport.

Also, $\mathrm{HCl}$ and $\mathrm{RCl}$ should be based on the connectivity of transport networks. Connectivity refers to the directness of travel between destinations (Sreelekha et al. 2016). It means that the highway and railroad construction is not only able to connect transport routes to tourist attractions, but it also contributes to the connectivity of different transport stations. For instance, $\mathrm{HCl}$ should be directed to railway stations in order to establish the connectivity between road and rail transport, which can provide the opportunity to construct an MMT or SST. Also, the connectivity of transport networks can lead to a better mobility of transport, which has a strict connection with tourism (La Rocca 2015).

There is another important concept in traveling and it is the concept of travel time. Accordingly, travelers would like to diminish the number of trips, to travel to closer destinations and to reduce the travel time for a given trip (Metz 2008). $\mathrm{HCl}$ and $\mathrm{RCl}$ can relatively reduce travel times and travel costs. One of the main tasks of the highways and railways is to provide the shortest routes with the best quality, and thus from this benefit the tourists to spend less time and expenses on traveling. 
One of the most considerable topics in promoting tourism are the safety and comfort of tourists, which can be achieved through the construction and improvement of highways and railways. Safety has always been an indispensable condition for travel and tourism (Kővári and Zimányi 2011) and the quality of transportation routes has a major impact on transport safety. The quality of highways and rail networks should be sufficiently high to minimize the risks of transport. On the other hand, if the transport routes are as short as possible, travelers spend less time on the routes and, obviously, with a reduced transport time, the risks of transport are reduced and this helps to improve the convenience and the comfort of travelers, which can lead to their satisfaction (Chan and Yuan 2017).

Fig. 4 visually shows the effect of each infrastructure integration factor on the effective transport-based factors in tourism promotion.

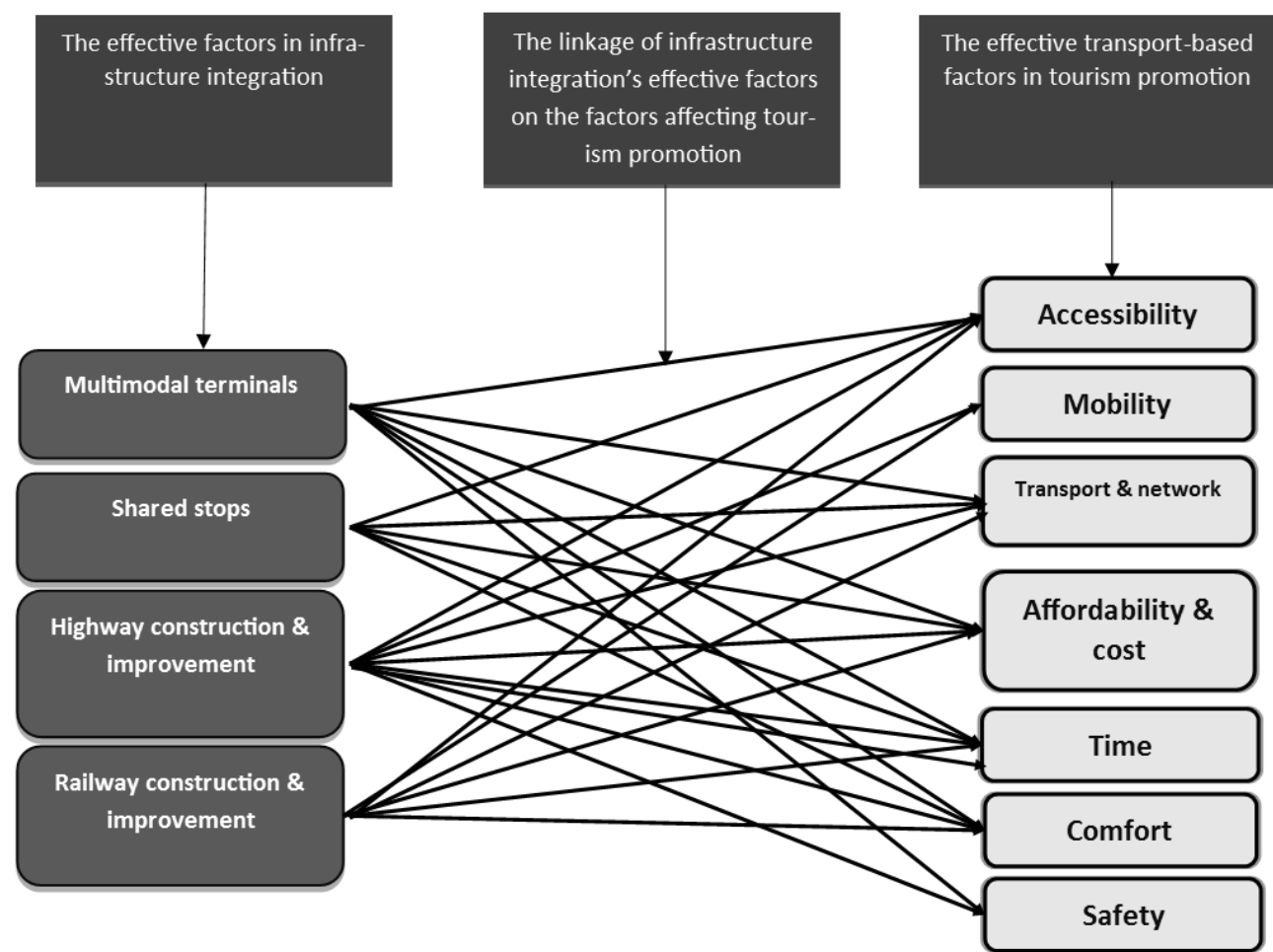

Fig. 4 - The effectiveness of the infrastructure integration factor on the effective factors in tourism promotion

The results of this study made it clear that IIRT is one of the effective transport-based strategies to promote the tourism industry. Such results are more important for tourism regions like Guilan, in which the infrastructures of different transport modes operate separately from each other with no integration.

Many studies have provided transport-based solutions to promote tourism and the relationship between transportation and tourism. So that, a gravity framework was employed by Khadaroo 
and Seetanah (2008) to evaluate the importance of transport infrastructure in determining the attractiveness of tourism destinations. The study was based on a panel data set of bilateral tourism flows among 28 countries over the decade 1990-2000. It was found that transport infrastructure is an important driver of the tourism entry to a destination and the evidence of repeated tourism around the world. Also, the disaggregated continent-wise analysis revealed that the sensitivity of tourism flows to transport infrastructure varies depending on the origin and destination (Khadaroo and Seetanah 2008).

Musa and Ndawayo (2011) examined the relationship between transportation (as measured by road connectivity, road condition) and the development of tourism (as measured by the location of national parks) in Nigeria, using an analysis that is performed on two levels, the disaggregate and the aggregate. A major finding of the study is that transportation is a significant determinant of tourism development in Nigeria. However, other factors that include access to recreational and social facilities and security also play a positive role, because they encourage patronage (Musa and Ndawayo 2011).

Chen and Haynes (2015) developed a method called the Spatial Econometric Computable General Equilibrium (SECGE) model which integrates both spatial econometrics with equilibrium modeling techniques to improve the effectiveness of impact analyses on transportation infrastructure. The results confirmed that the US highway and streets play an essential role among all transportation infrastructure systems in economic development, while public transit and passenger transport play only the least role among the systems. The results of the general equilibrium analysis also show the difference between the use of spatial econometric estimates and traditional OLS estimates. Although the differences in their aggregate case study are relatively minor, the implications for more sensitive disaggregated regional models are clear (Chen and Haynes 2015).

In the study of Gołembski and Majewska (2018), the purpose was to determine the importance of transport infrastructure among other classical factors of a gravity model that influence the foreign inbound tourism to Poland. Their study was based on panel data on bilateral tourism turnovers in the period 2008-2016 from 33 countries trading with Poland, and the results indicated that transport infrastructure development has a significant impact on foreign inbound tourism in Poland (Gołembski and Majewska 2018).

The study of Lumsdon (2000) evaluated the concept of a planned sustainable transport network, and the National Cycle Network in the UK, as a potential model for the integration of transport, tourism and leisure, and it concluded with a number of implications, which may be considered when developing similar tourism transport networks, while a model of sustainable transport development was presented (Lumsdon 2000).

Previous studies have pointed to important topics including various factors which influence the tourism industry such as: road conditions, attractiveness of tourism routes and transport infrastructure, in which the common result between the reviewed studies and this article is that transportation has a significant impact on tourism promotion. Our work provides IIRT as a transport-based strategy which can help regions to promote their tourism industry with a series of steps. In this sense, it would be helpful if governments could collaborate to enhance IIRT factors in the regions aiming to promote the tourism industry.

\section{Conclusions}

Surveys indicate the decisive role of transport in the tourism industry and the mutual relationship between tourism and transport and it was also found that IIRT, as a transport improvement system, can play a significant role in promoting tourism in a region. MMTs, SSTs, 
$\mathrm{HCls}$ and $\mathrm{RCls}$, as infrastructural integration factors, can have direct impacts on the factors which can lead to tourism promotion.

Guilan province, region with more than 1000 tourist attractions, is considered as one of the most important tourist areas in Iran and the Middle East. However, there are still many problems with the transportation of tourists in this province. On the other hand, given that Guilan province is profited with all four main modes of transport (road, rail, air and water), there is a good potential for the implementation of an integrated transport system in the province. Surveys showed that there were no MMTs or SSTs in the province, and the highway and rail network of the province were not as well-developed as they should have been, therefore, IIRT can help towards the promotion of the tourism industry in the province.

Furthermore, it is expected for the highway network to be expanded to the southeast and northwest parts of the province which lack a proper accessibility to transportation, and for the existing networks to be improved. Also, Rasht-Anzali, Rasht-Astara and Rasht-Sari rail lines need to be put into operation as soon as possible and a passenger water transport infrastructure in Anzali and Astara ports will also be required.

On the other hand, in order to integrate the transportation of the province, MMTs and SSTs need to be established at the necessary points to create connectivity between the different modes of transport, including the creation of a multimodal air-road-rail terminal at the current range of Sardar-e jangal airport, shared stops at Anzali and Astara ports, and shared rail-road stops at the train stations in the province. It is expected that, with the realization of these strategies, the transportation of the province will be greatly improved and, consequently, the tourism industry of the province will also be promoted.

\section{References}

CHAN C.-S., YUAN J. (2017), Changing travel behaviour of high-speed rail passengers in China, Asia Pacific Journal of Tourism Research 22 (12), 1221-1237.

CHEN Z., HAYNES K. E. (2015), Spatial impact of transportation infrastructure: a spatial econometric CGE approach, in: Nijkamp P., Rose A., Kourtit K. (eds.), Regional Science Matters: Studies Dedicated to Walter Isard, Springer, Cham, pp. 163-186.

CROUCH G. I., RITCHIE J. R. B. (1999), Tourism, competitiveness, and societal prosperity, Journal of Business Research 44 (3), 137-152.

GIVONI M., BANISTER D. (2010), Integrated Transport: from policy to practice, Routledge, London.

GOŁEMBSKI G., MAJEWSKA J. (2018), The impact of transport infrastructure on international Inbound tourism - A gravity model for Poland, International Journal of Contemporary Management 17 (4), 133-152.

GUTIERREZ A., MIRAVET D., SALADIÉ Ò., CLAVÉ S. A. (2019), Transport Mode Choice by Tourists Transferring from a Peripheral High-Speed Rail Station to Their Destinations: Empirical Evidence from Costa Daurada, Sustainability 11 (11), 3200.

HINE J. (2000), Integration, integration, integration... Planning for sustainable and integrated transport systems in the new millennium, Transport Policy 7 (3), 175-177.

HULL A. (2005), Integrated transport planning in the UK: From concept to reality, Journal of Transport Geography 13 (4), 318-328.

IBRAHIM M. F. (2003), Improvements and integration of a public transport system: the case of Singapore, Cities 20 (3), 205-216.

ISRAELI Y., MANSFELD Y. (2003), Transportation accessibility to and within tourist attractions in the Old City of Jerusalem, Tourism Geographies 5 (4), 461-481. 
JANIC M. (2001), Integrated transport systems in the European Union: An overview of some recent developments, Transport Reviews 21 (4), 469-497.

KHADAROO J., SEETANAH B. (2008), The role of transport infrastructure in international tourism development: A gravity model approach, Tourism Management 29 (5), 831-840.

KÖVÁRI I., ZIMÁNYI K. (2011), Safety and Security in the Age of Global Tourism (The changing role and conception of Safety and Security in Tourism), Applied Studies in Agribusiness and Commerce 5 (3-4), 59-61.

KREJIĆ Ž., PLEČIĆ K. (2016), Competitiveness of Vojvodina as a tourism destination: the analysis of selected travel \& tourism competitiveness index indicators, SITCON 2016: Quality as a basis for tourism destination competitiveness, 49-58.

LA ROCCA R. A. (2015), Tourism and Mobility. Best Practices and Conditions to Improve Urban Livability, TeMA - Journal of Land Use, Mobility and Environment 8 (3), 311 330.

LOHMANN G., PEARCE D. G. (2012), Tourism and transport relationships: The suppliers' perspective in gateway destinations in New Zealand, Asia Pacific Journal of Tourism Research 17, 14-29.

LU M., HSU S.-C., CHEN P.-C., LEE W.-Y. (2018), Improving the sustainability of integrated transportation system with bike-sharing: A spatial agent-based approach, Sustainable Cities and Society 41, 44-51.

LUMSDON L. (2000), Transport and tourism: cycle tourism - a model for sustainable development?, Journal of Sustainable Tourism 8 (5), 361-377.

MADHUWANTHI R. A. M., MARASINGHE A., RAJAPAKSE R. P. C. J., DHARMAWANSA A. D., NOMURA S. (2015), Factors influencing to travel behavior on transport mode choice: A Case of Colombo Metropolitan Area in Sri Lanka, International Journal of Affective Engineering 15 (2), 63-72.

MAMMADOV R. (2012), The importance of transportation in tourism sector, 7th Silk Road International Conference "Challenges and opportunities of sustainable economic development in Eurasian countries", 381-386.

MAY A. D., KELLY C., SHEPHERD S. (2006), The principles of integration in urban transport strategies, Transport Policy 13 (4), 319-327.

MAY A. D., ROBERTS M. (1995), The design of integrated transport strategies, Transport Policy 2 (2), 97-105.

METZ D. (2008), The myth of travel time saving, Transport Reviews 28 (3), 321-336.

MUSA I. J., NDAWAYO B. A. (2011), The role of transportation in the development of tourism in Nigeria, Tourismos: an international multidisciplinary journal of tourism 6 (1), 297305.

NAJDAWI A. (2009), SOA and web services for leveraging inter-organizational integration in travel and tourism, 2009 Congress on Services-I, 151-154.

NOSAL K., SOLECKA K. (2014), Application of AHP method for multi-criteria evaluation of variants of the integration of urban public transport, Transportation Research Procedia 3 , 269-278.

PENG B., SONG H., CROUCH G. I., WITT S. F. (2015), A meta-analysis of international tourism demand elasticities, Journal of Travel Research 54 (5), 611-633.

POTTER S., SKINNER M. J. (2000), On transport integration: a contribution to better understanding, Futures 32 (3-4), 275-287.

PRESTON J. (2010), What's so funny about peace, love and transport integration?, Research in Transportation Economics 29 (1), 329-338.

SANTOS M. C., FERREIRA A. M., COSTA C. (2014), Influential factors in the competitiveness of mature tourism destinations, Tourism \& Management Studies 10 (1), 73-81.

SHIN Y.-S. (2005), Safety, security and peace tourism: The case of the DMZ area, Asia Pacific Journal of Tourism Research 10 (4), 411-426.

SOLECKA K., ŻAK J. (2014), Integration of the urban public transportation system with the application of traffic simulation, Transportation Research Procedia 3, 259-268. 
SORUPIA E. (2005), Rethinking the role of transportation in tourism, Proceedings of the Eastern Asia Society for Transportation Studies 5, 1767-1777.

SREELEKHA M. G., KRISHNAMURTHY K., ANJANEYULU M. V. L. R. (2016), Interaction between road network connectivity and spatial pattern, Procedia Technology 24, 131-139.

STEAD D. (2003), Transport and land-use planning policy: really joined up?, International Social Science Journal 55 (176), 333-347.

TÓTH G., DÁVID L. (2010), Tourism and accessibility: An integrated approach, Applied Geography 30 (4), 666-677.

TURNBULL K. F., GRIFFIN G. P. (2012), Transportation and Tourism, University Transportation Center for Mobility, Retrieved from: www.utcm.tti.tamu.edu.

(3), 159-169

UNDERDAL A. (1980), Integrated marine policy: What? Why? How?, Marine Policy 4

VAN TRUONG N., SHIMIZU T. (2017), The effect of transportation on tourism promotion: Literature review on application of the Computable General Equilibrium (CGE) Model, Transportation Research Procedia 25, 3096-3115.

WANG S., CHEN J. S. (2015), The influence of place identity on perceived tourism impacts, Annals of Tourism Research 52, 16-28.

WORLD TOURISM ORGANIZATION (2019), International Tourism Highlights, 2019 Edition, UNWTO, Madrid.

YANG Y., LI D., LI X. R. (2019), Public transport connectivity and intercity tourist flows, Journal of Travel Research 58 (1), 25-41.

YAO L.-F., LONG R.-Y., LIU A.-Y., QINGCHEN L. (2011), Cointegration relationship analysis of tourism and transportation in China, 2011 International Conference on Business Management and Electronic Information, 141-144.

ZENG B., HE Y. (2019), Factors influencing Chinese tourist flow in Japan - a grounded theory approach, Asia Pacific Journal of Tourism Research 24 (1), 56-69.

ZHANG C. X., DECOSTA P. L. E., MCKERCHER B. (2015), Politics and tourism promotion: Hong Kong's myth making, Annals of Tourism Research 54, 156-171.

Initial submission: 01.12.2019

Revised submission: 26.05.2020

Final acceptance: 04.06.2020

Correspondence: Department of Regional Planning, University of Guilan, Rasht, Iran.

Email: maleki.mohammad.1994@gmail.com 
